\title{
Understanding Policy Change: Multiple Streams and National Education Curriculum Policy in Hong Kong
}

\author{
Anthony Chow \\ Graduate School of Education, University of Bristol \\ 35 Berkeley Square, Bristol BS8 1JA, United Kingdom \\ E-mail: a.chow@bristol.ac.uk
}

Accepted: April 02, 2014

Doi:10.5296/ jpag.v4i2.5184 URL: http://dx.doi.org/10.5296/ jpag.v4i2.5184

\begin{abstract}
The purpose of this paper is to critically analyse the policymaking process of the Moral and National Education (MNE) curriculum in Hong Kong by employing Kingdon's Multiple Streams Framework. The aim of the paper is threefold. First, it will describe the policy process of the national education curriculum policy as a foundation for the analysis. Second, the author will critically evaluate and apply Kingdon's MSF to examine the policymaking process, both to analyse how such policy came to be constructed as a problem and to consider the proposed policy solutions, as well as the surrounding political forces. Third, the analysis will identify the possible coupling of these lines of thought and the notions of "policy entrepreneurs" and "policy windows."

The MNE policy provided a good example of how a policy problem is constructed in various policy contexts, as well as how the solution is matched to the problem. Although the policy outcome is not entirely predictable, Kingdon's framework is excellent for explaining the likely outcomes.

This paper contributes to the wider policy literature by bridging the East-West gap in policy analysis. It provides a better understanding of the policymaking process in Asian countries, and it should also prove useful to both education policy scholars and policymakers. Finally it suggests further research is needed on how social media affects each of Kingdon's streams in Hong Kong.
\end{abstract}

Keywords: Educational policy, multiple streams framework, agenda setting, policy analysis, curriculum policy 


\section{Introduction}

This paper will use Kingdon's (1995) Multiple Streams Framework (MSF) to critically analyse the policymaking process of the national education curriculum in Hong Kong. The aim of the paper is threefold. First, it will describe the policy process of the national education curriculum policy as a foundation for the analysis. Second, I will critically evaluate and apply Kingdon's MSF to examine the policymaking process, both to analyse how the national education curriculum policy came to be constructed as a problem and to consider the proposed policy solutions, as well as the surrounding political forces. Third, the analysis will identify the possible coupling of these lines of thought and the notions of "policy entrepreneurs" and "policy windows."

The applicability of the MSF outside the US political environment has always been a hotly debated topic in the literature. This paper contributes to theoretical knowledge by applying this framework to Hong Kong, thereby further confirming its usability in an Asian context. It is also intended to assist policymakers in better understanding and managing the policymaking process.

\section{The National Education Curriculum Policy in Hong Kong}

This section will introduce the policy background, problem, and process, as well as the surrounding politics. It also sets out the basis and context for the case presented later.

Launching Moral and Civic Education was one of the four key tasks of the 2001 curriculum reform undertaken by the Hong Kong government (Thomas, 2005). In its policy addresses from 2007 to 2010, the government announced that a new Moral and National Education (MNE) curriculum would replace the existing Moral and Civic Education curriculum to "strengthen national education" (Kennedy, 2013).

The government planned to introduce this new subject across all local schools in 2012, and a four-month public consultation period began in 2011 (EDB, 2011). This was initiated along with many other new education policies, such as changes in mediums of instruction and the introduction of Putonghua as a compulsory subject in all schools, with the aim of increasing students' loyalty towards the People's Republic of China (PRC) (Choi Tse\& Kwan, 2007).

There is no lack of debate every time the government introduces a new educational policy in Hong Kong. From the point of view of educators and parents, the MNE policy carries a hidden agenda and represents an attempt by the government to "brainwash" students. In this light, Parents through the media requested that the government put a hold on the policy and call immediately for further public consultation (Yang, 2012). This claim was loud and clear; however, the government underestimated the situation and did not act before the ideal time had passed. The delayed response ignited several major demonstrations and eventually led to a turnaround in the policymaking process (SCMP, 2012g).

People had valid reasons for concern. They believed the teacher's manual was largely subjective and biased towards the PRC (MPD, 2012a). For instance, the manual stated that "multi-party politics (e.g. USA) could victimise people, while concentrated political power 
(e.g. PRC) could create selfless governments that bring about stability" (Centre, 2012, p. 10). Unsurprisingly, the development of these contents was well supported financially. The government admitted that over the past six years, more than HKD 72 million had been granted to two Beijing-loyalist companies to produce this teacher's manual (Cheung, 2012). The education minister admitted that, although the manual's content was biased, he thought that students could evaluate the content critically with teachers' guidance. According to Mingpao Daily (2012b), educators and parents considered this rhetoric deceptive and unacceptable.

The surrounding political forces were also strong. The government insisted on launching the MNE policy, and stressed that most schools had received extra funding to support this new subject (SCMP, 2012i). PRC officials constantly gave speeches at public events to pressure those opposed, while local politicians were polarised on this issue, and international voices also started coming in (SP, 2012).

Scholarism, the largest student-led political group, organised a 120,000-person demonstration just two days before the legislative election (SCMP, 2012e), successfully capturing media attention worldwide (HKP, 2012). After this policy problem became a crisis, the government finally agreed to "shelve" the MNE policy and allowed schools to decide whether or not they would utilise this new curriculum.

\section{A Critical Evaluation of Kingdon's Multiple Streams Framework}

This section will critically evaluate Kingdon's (1995) Multiple Streams Framework (MSF) and discuss related criticism in the academic literature. The MSF first appeared in Kingdon's (1995) book, entitled Agendas, Alternatives and Public Policies; it is a useful theoretical perspective for understanding the MNE curriculum policy change in Hong Kong. This framework argues that the policy process is often dynamic and irrational due to ambiguity in the real policymaking environment (Zahariadis, 2003). Traditional policymaking models assumed that all decisions were rational and that the policymaking process was systematic. However, such a linear process might not accurately reflect all situations (Teodorović, 2008).

The MSF is also widely used to explain state-level educational policymaking process, such as state decentralization of higher education (McLendon, 2003), teacher tenure (Elrod, 1994), student diversity (Stout \& Stevens, 2000), gifted education (Holderness, 1990), and school reforms (Lieberman, 2002). However, there has been no previous study of the MSF framework in a postcolonial educational context.

\subsection{The Paradigm Shift in Policy Studies}

The debate regarding scientific evidence for policy studies has raged unabated for over a century (Lilford \& Braunholtz, 1996). The traditional dominant policy models are derived from a positivist epistemology; therefore, all share a common rationalist approach (Etzioni, 1967). Rationalists see policymaking as a linear process that goes from problem identification to the analysis of alternatives to recommending policy solutions. Smith (2010) explained that central to this approach is the scientific approach, in which policy scholars set out to implement rigorous methodology with the aim of assembling a generalizable model. 
However, this approach tends to overlook the fact that the policy process can have a kind of randomness, and that it can also be affected by external factors, such as timing, national mood, or political ideologies (Black, 2001).

Colebatch (2006) argued that discussions regarding alternative approaches are limited, but that policy scholars should use rationalist models with care. Many policy scholars have found that not all policymaking processes are rational in nature (Monaghan, 2011). Ackrill and Kay (2011) maintained that policy scholars needed an alternative framework to deal with the ever-changing policymaking environment, which contains a complex set of interactions with multiple actors, often with competing objectives (Cohen, March, \& Olsen, 1972; Haas, 1992; Hoppe, 2011; Sabatier, 1988).

In contrast to traditional rationalist models, Kingdon's frequently cited MSF addresses ambiguity, representing a major paradigm shift in the field of policy studies (Nutley, Walter, \& Davies, 2007), offering an alternative that is more relevant to the real world (Pollitt, 2008, p. 127)."

\subsection{The Multiple Streams Framework}

The main underlying assumption of the MSF is the belief that policymaking is "dynamic, irrational and unpredictable" (Nutley, Walter, \& Davies, 2007), and the surrounding environment is always ambiguous and complex (Pollitt, 2008, p. 127). Zahariadis (2003) suggested that ambiguity may be defined as the state of having many ways of thinking about the same problem. Furthermore, ambiguity may also evoke confusion and stress, but it differs from uncertainty, which means the inability to predict an event accurately (Zahariadis (2007).

The framework centres on the key concepts within three different streams that are floating in constant parallel within the policymaking environment. According to Kingdon (1995), these streams are the problem stream, the policy stream, and the politics stream. The problem stream refers to issues capture everyone's attention, including the government. The policy stream can be conceptualised as a "policy primeval soup" (Kingdon, 1995, p.116) in which policy ideas and solutions are formed, developed, rejected, and selected. The politics stream refers to public opinion, election results, and demands of interest groups.

Kingdon maintained that when the three streams joined at critical moments, they would constitute a policy window. Kingdon (1995, p. 20) explained that when this window opens, the issue becomes a part of the policy agenda and subsequent policymaking steps will ensue. The coupling of streams is determined by the presence of policy windows and the actions of policy entrepreneurs. Policy entrepreneurs are actors who introduce and promote their ideas on many occasions, investing time and energy to increase their chances of getting an idea placed on the decision-making agenda (Kingdon, 1995). They are active in both the problem stream and the policy stream, and they must act quickly when the policy window opens, or the opportunity will pass them by (Zahariadis, 2007).

\subsection{The Strengths of the Multiple Streams Framework}

Kingdon's MSF is an enhanced version of the Garbage Can Model of organisational choices 
developed by Cohen, March, and Olsen in 1972 (Parsons, 1995, p. 192). The original Garbage Can Model is designed for a pluralist environment with multiple actors, objectives, and views, and it contributed to the basic understanding of how decisions are made in an ambiguous environment (Turpin \& Marais, 2004). The MSF extends this concept to the state level and explains how and why certain policy issues move onto a government's agenda while others do not (Sabatier, 1999).

Kingdon's framework is empirically based, with data from 247 interviews with transportation and health policymakers in the US (Cohen-Vogel \&McLendon, 2009). He developed an explanation of policy change that adapted some elements of rationalism, while rejecting the traditional problem-solving and incremental models of policy formation. In addition to providing an alternative framework that can accommodate ambiguity in the policymaking process (John, 1998, p. 173), the MSF also aims to examine three issues: a) how policymakers' attention is captured; b) how problems are formed; and c) the problem-solution matching process.

\subsection{The Limitations of the Multiple Streams Framework}

The MSF has not escaped criticism from scholars and policymakers. Although the framework addresses the reality of policymaking, there are limits on how far the concept can be taken. One of the more frequent critiques is that Kingdon made no attempt to test the framework outside the US (Sabatier, 1999). Crucially, the political environment in the East differs from that in the West because of differences in culture, history, and political ideology. Eastern politics are grounded in New Confucianism and guangxi (relationships) (Bell, 2010), while the foundation of Western politics is law and policy (Chow, 1991). In its current form, the MSF is not thoroughly prepared to accommodate Eastern politics. Sabatier (1999) suggested that if Kingdon were to expand the framework to account for Eastern particularities, the scholarship on the topic would be more valuable, both theoretically and empirically.

Another limitation is that the MSF did not sufficiently acknowledge the significance of media effects, including the social media (Stout \& Stevens, 2000). The amplification effect of the media is inevitable, and its importance in the policy process is also well established. Elder and Cobb (1983) contended that the media could escalate issues on the policy agenda, increasing their chances of receiving government consideration. According to the Theory of Agenda Setting in the field of communication, the media does not reflect reality, but simply filters and shapes it according to audience interest (Scheufele, 1999, 2000). This is critical for the MSF, as policy entrepreneurs could manipulate stream development by carefully managing the media (Shanahan, McBeth, Hathaway, \& Arnell, 2008).

More recent arguments against the MSF relate to whether the streams are truly independent (Sabatier, 1999). This is difficult to ensure, given the ever-changing and ambiguous nature of reality (Robinson \& Eller, 2010). However, the streams provide good analytical categories. Each has its own rules and flows largely independently of the others (Guldbrandsson \& Fossum, 2009). Streams merge only when policy entrepreneurs attach problems to solutions and present them to receptive political audiences. Stout and Stevens (2000) supported this argument, asserting that such flexibility is in fact necessary in the policy paradigm, since 
researchers are not seeking statistical excellence, but rather the best interpretation of the information in each stream.

\section{The Multiple Streams Framework in the Context of the MNE Curriculum Policy}

Context matters in selecting a framework for policy analysis (Holderness, 1990). The education policy in Hong Kong is multidimensional, so it is difficult to explain in a rational, linear, and structured manner (Johnson, 1997). With a population of only seven million people, Hong Kong has more than 15 active political parties proposing different education policy initiatives. Nonetheless, the PRC exerts the most pressure on policymaking in its attempts to push its decolonisation agenda (Postiglione, 1992).

Given the political climate in Hong Kong, the MSF's three key assumptions-fluid participation, problematic preferences, and unclear technology-make it the most suitable analytical framework for analysing the MNE policy. First, the fluid participation of government officials affects rationality and predictability. For instance, as Robinson and Eller (2010) explained, participants at any meeting may vary considerably, and different officials may devote different levels of energy to the decision-making process. In one case, the government had sent more than five officials to try to mediate with the government (SCMP, 2013), but all of these officials had different goals. Thus, policy analysts had difficulty identifying who had held the de facto power, making the outcome unpredictable (SCMP, 2013). Furthermore, the addition of the random voice of pressure groups made the situation even more unpredictable.

Second, in most situations, preferences are unclear and problematic, mainly because they are poorly defined or articulated, and there are multiple objectives (Robinson and Eller (2010). For instance, the chief executive of Hong Kong once commented to the media on 4 September 2012 vaguely, "between withdrawing and not withdrawing the subject, there is much room for discussion between the government and those opposed to the subject." Most people perceived this as an empty gesture, and the chief executive refused to further clarify his meaning (MPD, 2012a).

Third, Ma and Xiao (2012) explained that unclear technology leads to unclear pathways to common goals. In the statement from the chief executive, the government's position is not well presented, nor is it understood by other political parties and pressure groups. Therefore, participants may know their parts, but not the "big picture" (Sabatier, 1999).

Thus, since the Hong Kong context is in line with all of these assumptions, the MSF is clearly the most suitable framework for our analysis.

\section{Convergence of the Three Streams: The MNE Curriculum Policy}

Following from the earlier sections in the paper, I will apply Kingdon's MSF as a theoretical framework to examine the MNE policymaking process. Through this, we will analyse how said policy came to be defined as a problem, considering the proposed policy solutions and the surrounding political forces. Finally, then I will discuss the possible merging of the streams, as well as the notions of "policy entrepreneurs" and "policy windows." 


\subsection{The Problem Stream}

The problem stream refers to problems that require immediate attention and action from the government (Kingdon, 2003, p. 198). These may come to the attention of government through feedback on existing policy programmes, with a focus on events like crises or strong indicators, such as statistics (Kingdon, 1984, p. 20).

\subsubsection{Feedback on existing programmes}

In terms of capturing government attention, three major voices emanate from educators and parents. First, approximately 10 percent of public school students are non-Chinese ethnic students. Their parents have argued that this is not fair to ethnic minorities as some of the teaching contents are contradictory to their own values. (SCMP, 2012b).

Second, the launch of the MNE curriculum is an added burden to students because a considerable component of it is duplicated in the existing Civic Education curriculum, and parents saw no need for this new subject (SCMP, 2012d).

Third, the public has noted a substantial amount of controversial content in the government-published "China model national conditions teaching manual" (Lai, 2012), with alarming favouritism towards the PRC, which was out of line with parents' expectations of more neutral contents (Carr, 1991; MPD, 2012a). For example, the manual described the Communist party as an "advanced, selfless and united ruling group," while defining the Democratic and Republican parties of the United States as a "fierce inter-party rivalry that makes people suffer" (NESC, 2012, p. 10). Primary students are not mentally prepared to take a critical stance, so the content should not be presented in this manner. Parents worried that this biased content would be taught as "reality" to students, and more seriously, that it would deny Hong Kong's next generation freedom of thought (STD, 2012).

\subsubsection{Focusing events and indicators}

The government underestimated the dissident voices, and the protestors became more aggressive. There were two focusing events that demonstrated that the problem had successfully caught the general public's attention.

First, 1,075 young scholars in Hong Kong signed a petition requesting that the government fully withdraw the MNE policy and to allow the public to participate in the consultation process (Petition_National_Education, 2012; STD, 2012). The petition initiators shared their concerns via social media platforms; the message spread quickly, and many scholars subsequently joined the petition. The event also attracted significant donations from the general public, which enabled the publication of the petition announcement in a major local newspaper(Petition_National_Education, 2012).

Second, in July 2012, more than 90,000 citizens participated in street protests to oppose the launch of the MNE policy. Not long after, more than 8,000 university students boycotted class, requesting that the policy to be stopped immediately. On September 7, 2012, Scholarism, a student-led political group, managed to gather 120,000 protesters in front of government headquarters (SCMP, 2012e), which attracted over 100 reporters from over 25 
countries (HKP, 2012).

This policy problem is complex, and together these events have successfully captured the government's attention.

\subsection{The Policy Stream}

The policy stream contains all the possible solutions to the problems generated by policy experts, such as government officials, analysts, scholars, and politicians. Kingdon (1995, p. 200), citing a famous metaphor, described all policy options as floating in the "the primeval policy soup" (p. 200), just waiting to be selected. Policy experts group them together, and the most feasible options appear on the agenda. In our case, the public voice is clear; the majority wants the immediate withdrawal of the policy and a re-initiation of the consultation process (SCMP, 2012g). While this may make sense for educators, parents, and students, particularly because it has to do with a policy proposal that would directly affect the next generation, withdrawal has its own challenges. This would directly affect the government's credibility and thus, its power to govern.

Three considerations led the chief executive to disagree on policy withdrawal. First, though the government faces many different pressures and has limited options, the pressure from the PRC was visible. Although both the media and citizens' voices called for a halt in the MNE policy, the Hong Kong chief executive had repeatedly expressed that withdrawal was not an acceptable solution (SCMP, 2012i). Most of the education policies after 1997 were implemented for decolonization reasons, and the MNE policy is no exception (Leung, 2013; Postiglione, 1992). For example, there was the controversial change of medium of instruction in secondary schools from English to Chinese, which was later proven to be very problematic for English-language proficiency and university articulation (Kan\& Adamson, 2010).

Second, the chief executive maintained that the policy had been going through a thorough consultation process since 2011. However, he refused to meet with the pressure group, such as the parents and educators, to explain why the key teaching manual was released only three months before the policy launch (SCMP, 2012i). The government missed an opportunity to mediate this crisis, lost to the policy entrepreneur.

Third, the government has paid HKD 50 million to a pro-Beijing agency to develop the key teaching materials for the MNE. The size of this investment suggests that no funds were left to redesign the curriculum from scratch (SCMP, 2012h).

One of the suggestions given by the policy experts was to "shelve" the MNE and allow schools to decide whether to teach the new MNE curriculum. This would still meet the PRC's expectation that the subject would be launched, and it was the best alternative option at that time (SCMP, 2012a).

\subsection{The Politics Stream}

The politics stream includes factors such as the national mood, administrative or legislative turnover, and pressure group campaigns (Kingdon, 1995, p. 21). Hong Kong's competitive advantages lie in its freedom of thought, political stability, and safe environment. The 
national mood is closely linked to these elements; people in Hong Kong work hard to protect these core values (SCMP, 2012c). At this point, one of the greatest fears of accepting the MNE policy is the disappearance of justice and democracy, a complete demolition of what older citizen took decades to build (SCMP, 2012c).

\subsubsection{National mood}

The national mood veers towards the withdrawal of the MNE policy, as its biased materials are perceived as problematic for the next generation (SCMP, 2012d). Recent research on ethnic identity showed that only 12.6 percent of the population identified themselves as "Chinese"; this is the lowest proportion on record since 1996 (HKU, 2013). At the same time, there was a significant rise in the number of those who "reject" the Chinese national flag and the Chinese anthem when compared to similar research done in 2010 (SCMP, 2012f). This is a powerful indication of diminishing trust between the government and the public.

Moreover, invisible pressure from the PRC on the Hong Kong government ensures the near impossibility of withdrawal (SCMP, 2012i). The pro-Beijing camp arranged for one of the major TV stations to broadcast a controversial message that called the Democratic party a "destructive group," a "theatrical" and "radical" "political demagoguery" with "scant respect for civic morals, the rule of law and public accord"; it also stated that "London and Washington were behind the anti-national education campaign." This action upset many Hong Kong residents, and the broadcasting authority received over 42,000 written complaints, an all-time high (AM730, 2012).

\subsubsection{Election}

Currently, over 61 percent of policymakers are from the pro-Beijing camp; their vote is critical in forming the policy agenda. Before the legislative election, the government was forced to respond to the MNE policy or risk the loss of their majority in the legislative council. The pro-Beijing party leaders told the media that they were assessing the feasibility of withdrawal of the policy and that they hoped to save some of the votes (AppleDaily, 2012).

\section{Policy Windows, Policy Entrepreneurs, and the Convergence Process}

Policy entrepreneurs attempt to merge the three streams and put forward their agenda to policymakers (Kingdon, 1995). While Young, Shepley, and Song (2010) noted that several other MSF-based studies in education policy had found that the government was acting as the policy entrepreneur, this case is an exception. Here, Scholarism, the student-led political party, was the policy entrepreneur that successfully merged all three streams.

Scholarism went through the process of capturing government attention in the problem stream by gathering protestors (SCMP, 2012e). This high-impact action effectively caught the attention of much international media, as well. The protest was organised two days before the legislative election, which was the right timing for the politics stream. In the policy stream, Scholarism fought for full policy withdrawal at the beginning, although they knew that this was probably not feasible. However, they correctly predicted that the government eventually would agree to a solution close to the original request. They successfully managed to merge 
all three streams when the policy window was opened - the right level of attention at the right time with a feasible policy alternative. Figure 1 summarizes the convergence process.

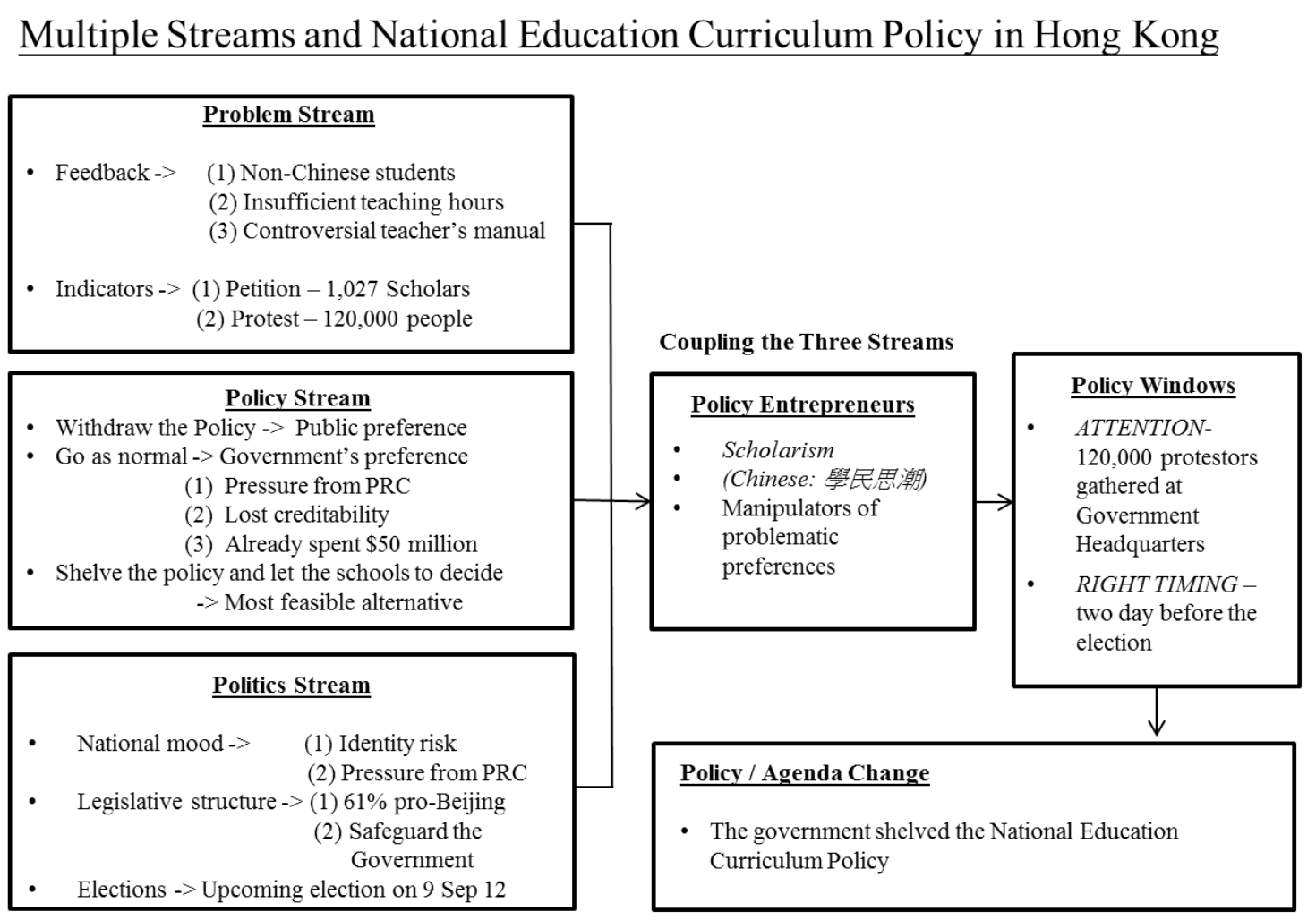

Figure 1. Multiple streams and National Education Curriculum Policy in Hong Kong

\section{Conclusion}

This paper has critically evaluated Kingdon's MSF as an analytical framework for the MNE policy in Hong Kong. I agree with Kingdon, who noted that the study and practice of education policy are always contested terrain (Lagemann, 1997), especially in a postcolonial era (Rizvi, Lingard, \& Lavia, 2006). Policy is inherently complex, and Kingdon's framework, based on a post-positivist epistemology, also allows the analyst to interpret deeper meanings through the analysis of different streams (Dudley, Parsons, Radaelli, \& Sabatier, 2000).

The MNE policy case used in this study provided a good example of how a policy problem is constructed in various policy contexts, as well as how the solution is matched to the problem. Although the policy outcome is not entirely predictable, Kingdon's framework was excellent for explaining the likely outcomes. The definition of the problem was not fixed; it was constantly evolving. Therefore, the success of the convergence strategy also depends on political sensitivity and time management. In the case of the MNE policy, the situation would have been quite different had Scholarism organised the protest after the election period.

Although the framework is unique and useful, policy scholars should nonetheless be aware of its limitations. Throughout the analysis, I often found information on policy alternatives to be 
both classified and sensitive in nature, and policy scholars may be unable to obtain such information. Depending on the transparency of the government, it is also difficult to determine whether the policy under analysis is a standalone policy, or if it is actually part of a larger set of political moves.

Finally, further research is needed on how social media affects each stream in Hong Kong, where the media penetration rate is above 50 percent overall and over 99 percent among students (Lam, Lee, Chan, \&McNaught, 2011). This analysis contributes to the wider policy literature by bridging the East-West gap in policy analysis. It provides a better understanding of the policymaking process in Asian countries, and it should also prove useful to both education policy scholars and policymakers.

\section{References}

Ackrill, Robert, \& Kay, Adrian. (2011). Multiple streams in EU policy-making: the case of the 2005 sugar reform. Journal of European Public Policy, 18(1), 72-89. http://dx.doi.org/10.1080/13501763.2011.520879

AM730. (2012). 亞視被轟抹黑學民思潮過萬投訴《ATV 焦點》(Over 10,000 people complains ATV brordcasting serious misleading messages), AM730. Retrieved from http://www.am730.com.hk/article.php?article=120088

AppleDaily. (2012, July 24). 難敵民意升溫 建制派曾為選票轉軚 (The pro-Beijing parties object to the national education to save the vote), Apple Daily. Retrieved from http://hk.apple.nextmedia.com/news/art/20120724/16541859

Bell, Daniel A. (2010). China's New Confucianism: Politics and Everyday Life in a Changing Society (New in Paper): Princeton University Press.

Black, Nick. (2001). Evidence based policy: proceed with care. BMJ: British Medical Journal, 323(7307), 275. http://dx.doi.org/10.1136/bmj.323.7307.275

Carr, Wilfred. (1991). Education for citizenship. British Journal of Educational Studies, 39(4), 373-385. http://dx.doi.org/10.1080/00071005.1991.9973898

Cheung, Tony. (2012, September 9). A history of how national education was introduced in Hong Kong, Scout China Morning Post. Retrieved from http://www.scmp.com/news/hong-kong/article/1032512/history-how-national-education-wasintroduced-hong-kong

Choi Tse, \& Kwan, Thomas. (2007). Remaking Chinese identity: hegemonic struggles over national education in post-colonial Hong Kong. International Studies in Sociology of Education, 17(3), 231-248. http://dx.doi.org/10.1080/09620210701543908

Chow, Rey. (1991). Woman and Chinese modernity: The politics of reading between West and East: University of Minnesota Press Minneapolis.

Cohen-Vogel, L, \& McLendon, M. (2009). New approaches to understanding federal involvement in education. Handbook of education policy research, 735-748. 


\section{Macrothink}

Journal of Public Administration and Governance

ISSN 2161-7104

2014, Vol. 4, No. 2

Cohen, Michael D, March, James G, \& Olsen, Johan P. (1972). A garbage can model of organizational choice. Administrative science quarterly, 1-25. http://dx.doi.org/10.2307/2392088

Colebatch, Hal K. (2006). What work makes policy? Policy sciences, 39(4), 309-321. http://dx.doi.org/10.1007/s11077-006-9025-4

Dudley, Geoffrey, Parsons, Wayne, Radaelli, Claudio M, \& Sabatier, Paul. (2000). Symposium: theories of the policy process. Journal of European Public Policy, 7(1), 122-140. http://dx.doi.org/10.1080/135017600343304

EDB. (2011). Consultation on Moral and National Education Curriculum. Hong Kong: Retrieved from http://www.edb.gov.hk/attachment/en/about-edb/press/consultation/consultation\%20on\%20m ne\%20curriculum\%20(summary)_2.pdf.

Elder, Roger W, \& Cobb, Charles D. (1983). Participation in American politics: The dynamics of agenda-building: Baltimore: John Hopkins University Press.

Elrod, Ann L. (1994). Teacher Tenure Reform: Problem Definition in Policy Formulation. Paper presented at the Annual meeting of the American Educational Research Association, New Orleans, L.A.

Etzioni, Amitai. (1967). Mixed-scanning: A" third" approach to decision-making. Public administration review, 385-392. http://dx.doi.org/10.2307/973394

Guldbrandsson, Karin, \& Fossum, Bjöörn. (2009). An exploration of the theoretical concepts policy windows and policy entrepreneurs at the Swedish public health arena. Health Promotion International, 24(4), 434-444. http://dx.doi.org/10.1093/heapro/dap033

Haas, Peter M. (1992). Knowledge, power, and international policy coordination: Univ of South Carolina Press.

HKP. (2012). 全球報導「7.29 反國民教育大遊行」(Worldwide reports on Anti-national education protest). Retrieved June 16, 2012, from http://goo.gl/n2wih

HKU. (2013). 市民的身份認同感 (People's Ethnic Identity). Retrieved 16 September 2013, 2013, from http://hkupop.hku.hk/english/popexpress/ethnic/

Holderness, Susan Tanner. (1990). The Politics of State Educational Policymaking: Usefulness of the Kingdon Model. In F. C. Wendel (Ed.), Issues of professional preparation and practice (pp. 17-31). University Park, PA: University Council for Educational Administration.

Hoppe, Robert. (2011). Institutional constraints and practical problems in deliberative and participatory policy making. Policy \& Politics, 39(2), 163-186. http://dx.doi.org/10.1332/030557310X519650

John, Peter. (1998). Analysing public policy: Burns \& Oates. 
Johnson, Robert Keith. (1997). Q The Hong Kong education system. Immersion education: International perspectives, 171.

Kan, Vincent, \& Adamson, Bob. (2010). Language policies for Hong Kong schools since 1997. London Review of Education, 8(2), 167-176. http://dx.doi.org/10.1080/14748460.2010.487336

Kennedy, Kerry J. (2013). Re-shaping education for citizenship-democratic national citizenship. Educational Studies(ahead-of-print), 1-2.

Kingdon, John W. (1984). Agendas. Alternatives, and Public Policies. Boston, 45.

Kingdon, John W. (1995). Agenda, alternatives and public policy. Boston: Little, Brown.

Kingdon, John W. (2003). Agendas, alternatives, and public policies. Boston: Little, Brown and Co.

Lagemann, Ellen Condliffe. (1997). Contested terrain: A history of education research in the United States, 1890-1990. Educational Researcher, 26(9), 5-17.

Lai, Alexis. (2012, July 30). 'National education' raises furor in Hong Kong, CNN. Retrieved from

http://edition.cnn.com/2012/07/30/world/asia/hong-kong-national-education-controversy

Lam, Paul, Lee, Jack, Chan, Mavis, \& McNaught, Carmel. (2011). Students' use of eLearning strategies and their perceptions of eLearning usefulness. Paper presented at the Global Learn.

Leung, Casey Kwong Chun. (2013). Reasons for Hong Kong Parents Sending Their Children Abroad for Secondary Education. University of Technology, Sydney.

Lieberman, Joyce M. (2002). Three Streams and Four Policy Entrepreneurs Converge A Policy Window Opens. Education and Urban Society, 34(4), 438-450. http://dx.doi.org/10.1177/00124502034004003

Lilford, RJ, \& Braunholtz, D. (1996). The statistical basis of public policy: a paradigm shift is $\begin{array}{lllll}\text { overdue. BMJ: British } & \text { Medical Journal, }\end{array}$ http://dx.doi.org/10.1136/bmj.313.7057.603

Ma, Juan, \& Xiao, Wenfa. (2012). Multiple Streams Framework and Land Privatization Policy in the United States-Pertaining to Property Rights Reform Concerns in China. Journal of US-China Public Administration, 9(1), 75-81.

McLendon, Michael Kevin. (2003). Setting the governmental agenda for state decentralization of higher education. The Journal of Higher Education, 74(5), 479-515. http://dx.doi.org/10.1353/jhe.2003.0038

Monaghan, Mark. (2011). Evidence versus politics: exploiting research in UK drug policy making? : Policy Pr.

MPD. (2012a, September 6). Editorial - National Education Should Be Withdrawn, Mingpao Daily. 
http://hk.news.yahoo.com/editorial-national-education-withdrawn-212750159.html

MPD. (2012b, July 6). 吳克儉指國民教育手冊有偏差 (The Education Minister admitted the National Education manual contrains biased contents), Mingpao Daily. Retrieved from http://inews.mingpao.com/htm/Inews/20120706/aa50843k.htm

NESC. (2012). 中國模式 - - 國情專題教學手冊 (China Model National Conditions Teaching Manual). Hong Kong: 國民教育服務中心 (National Education Service Centre).

Nutley, Sandra M, Walter, Isabel, \& Davies, Huw TO. (2007). Using evidence: How research can inform public services: The Policy Press.

Parsons, Wayne. (1995). Public policy. Cheltenham, Northampton.

Petition_National_Education. (2012, September 6). Young Scholars Petition to Rescind "Moral and National Education". Retrieved 26 May 2013, from http://nationaleducationpetition.blogspot.hk/

Pollitt, Christopher. (2008). Time, Policy, Management: Governing with the Past: Governing with the Past: OUP Oxford.

Postiglione, Gerard A. (1992). The decolonization of Hong Kong education. Education and society in Hong Kong: Toward one country and two systems, 3-38.

Rizvi, Fazal, Lingard, Bob, \& Lavia, Jennifer. (2006). Postcolonialism and education: Negotiating a contested terrain. Pedagogy, Culture \& Society, 14(3), 249-262. http://dx.doi.org/10.1080/14681360600891852

Robinson, Scott E, \& Eller, Warren S. (2010). Participation in policy streams: Testing the separation of problems and solutions in subnational policy systems. Policy Studies Journal, 38(2), 199-216. http://dx.doi.org/10.1111/j.1541-0072.2010.00358.x

Sabatier, Paul A. (1988). An advocacy coalition framework of policy change and the role of policy-oriented learning therein. Policy sciences, 21(2-3), 129-168. http://dx.doi.org/10.1007/BF00136406

Sabatier, Paul A. (1999). Theories of the policy process: Westview Press Boulder, CO.

Scheufele, Dietram A. (1999). Framing as a theory of media effects. Journal of communication, 49(1), 103-122. http://dx.doi.org/10.1111/j.1460-2466.1999.tb02784.x

Scheufele, Dietram A. (2000). Agenda-setting, priming, and framing revisited: Another look at cognitive effects of political communication. Mass Communication \& Society, 3(2-3), 297-316. http://dx.doi.org/10.1207/S15327825MCS0323_07

SCMP. (2012a, October 8). CE shelves national education guidelines after panel report, South China Morning Post. Retrieved from http://www.scmp.com/news/hong-kong/article/1056353/panel-advises-against-dropping-natio nal-education-classes

SCMP. (2012b, September 27). Education system ignores needs of ethnic minorities, South 
China

Morning

Post.

Retrieved

from

http://www.scmp.com/comment/insight-opinion/article/1047887/education-system-ignores-ne eds-ethnic-minorities

SCMP. (2012c, September 13). Hong Kong's Leung backs down on Chinese patriotism lessons, South China Morning Post. Retrieved from http://www.scmp.com/news/hong-kong/article/1032368/hong-kongs-leung-backs-down-chine se-patriotism-lessons?page=all

SCMP. (2012d, September 5). Hong Kong needs an alternative to national education, South

China Morning Post. Retrieved from
http://www.scmp.com/news/hong-kong/article/1029630/hong-kong-needs-alternative-nationa l-education

SCMP. (2012e, October 20). Leung 'caught off guard' by national education row, Wu says South China Morning Post. Retrieved from http://www.scmp.com/news/hong-kong/article/1065283/leung-caught-guard-national-educati on-row-wu-says

SCMP. (2012f, August 15). Locals Identity Chinese-citizens Hits 13-year Low, Scouth Morning China Post. Retrieved from http://www.scmp.com/article/1005101/locals-identity-chinese-citizens-hits-13-year-low

SCMP. (2012g, September 3). National education hunger strikers issue deadline, South China Morning Post. Retrieved from http://www.scmp.com/news/hong-kong/article/1028492/national-education-hunger-strikers-is sue-deadline

SCMP. (2012h, September 12). The price of an education, South China Morning Post. Retrieved from http://www.scmp.com/article/1001678/price-education

SCMP. (2012i, September 4). Withdrawing national education classes not an option, CY Leung says, South China Morning Post. Retrieved from http://www.scmp.com/news/hong-kong/article/1029305/withdrawing-national-education-notoption-leung-says

SCMP. (2013, May 13). Government ministers should think before they speak, South China Morning Post. Retrieved from http://www.scmp.com/comment/insight-opinion/article/1242315/government-ministers-shoul d-think-they-speak

Shanahan, Elizabeth A, McBeth, Mark K, Hathaway, Paul L, \& Arnell, Ruth J. (2008). Conduit or contributor? The role of media in policy change theory. Policy Sciences, 41(2), 115-138. http://dx.doi.org/10.1007/s11077-008-9058-y

Smith, Kevin B. (2010). The public policy theory primer: ReadHowYouWant. com.

SP. (2012, October 22). 千人上街撐國民教育 (Thousand supporters of Moral and National Education, 


\section{Macrothink}

Journal of Public Administration and Governance

ISSN 2161-7104

2014, Vol. 4, No. 2

http://www.singpao.com/xw/gat/201210/t20121022_396534.html

STD. (2012, September 5). 二百學者聯署促撤國教科 (Over 200 Scholars Signed on a Petition to stop National Education), Sing Tao Daily. Retrieved from http://www.singtao.com.hk/yesterday/edu/0905go08.html

Stout, Karen Evans, \& Stevens, Byron. (2000). The case of the failed diversity rule: A multiple streams analysis. Educational evaluation and policy analysis, 22(4), 341-355. http://dx.doi.org/10.3102/01623737022004341

Teodorović, Jelena. (2008). Why education policies fail: Multiple streams model of policymaking. Zbornik Instituta za pedagoška istraživanja, 40(1), 22-36. http://dx.doi.org/10.2298/ZIPI0801022T

Thomas, Tse Kwan Choi. (2005). Civic and political education Education and Society in Hong Kong and Macao (pp. 175-200): Springer.http://dx.doi.org/10.1007/1-4020-4449-6_12

Turpin, SM, \& Marais, MA. (2004). Decision-making: Theory and practice.

Yang, Kelly. (2012, September 11). National education fears reflect Hong Kong's lack of faith, South China Morning Post. Retrieved from http://www.scmp.com/comment/insight-opinion/article/1033563/national-education-fears-refl ect-hong-kongs-lack-faith?page=all

Young, Tamara Viola, Shepley, Thomas V, \& Song, Mengli. (2010). Understanding agenda setting in state educational policy: An application of Kingdon's multiple streams model to the formation of state reading policy. education policy analysis archives, 18(15), 1-23.

Zahariadis, Nikolaos. (2003). Ambiguity and Choice Un Public Policy: Political Decision Making in Modern Democracies: Georgetown University Press.

Zahariadis, Nikolaos. (2007). The multiple streams framework: Structure, limitations, prospects. Theories of the policy process, 2, 65-92. 